\title{
Phaeochromocytoma presenting as acute malignant hyperthermia - a diagnostic challenge
}

\begin{abstract}
We report a case of acute hypermetabolism following the induction of general anaesthesia in an $/ /$-yr-old boy. This episode was diagnosed and managed as an acute malignant hyperthermia crisis. However, severe hypertension during the episode led to the discovery of an unsuspected phaeochromocytoma. A hypermetabolic state during anaesthesia has several aetiologies, but correct diagnosis during the acute episode may be difficult.
\end{abstract}

On rapporte le cas d' une crise auguë d'hypermétabolisme aprés l'induction de l'anesthésie générale chez un enfant de $1 /$ ans. Cet épisode fut dianostiqué et traité comme une crise d'hyperthermie maligne. Cependant l'hypertension sévère durant l'épisode a amené la découverte d'un phéochromocytome non diagnostiqué. Un état hypermétabolique durant l'anesthésie a plusieurs étiologies mais le diagnostic exact durant l'épisode aigu peut être difficile.

A hypermetabolic response during anaesthesia and surgery is an unusual event that may occur with such diverse conditions as thyrotoxicosis, acute sepsis, phaeochromocytoma, and malignant hyperthermia (MH).' We report a patient who developed hypertension, tachycardia, hyperthermia, and respiratory acidosis, which was initially diagnosed as acute $\mathrm{MH}$. The discovery of an unsuspected phaeochromocytoma, and a negative caffeine halothane contracture test ruled out the diagnosis of MH.

\author{
Key words \\ ACID-BASE EQUILIBRIUM: acidosis, respiratory; \\ COMPLICATIONS: hypertension, pulmonary oedema; \\ HYPERTHERMIA: malignant; \\ METABOLISM: hyperthermia; \\ NEUROMUSCULAR RELAXANTS: dantrolene; \\ SURGERY: phaeochromocytoma.
}

From: The Department of Anesthesiology, MS 310, Hahnemann University, Broad and Vine Streets, Philadelphia, PA, 19102-1192.

Address Correspondence to: Dr. H. Rosenberg.

\section{Case Report}

An 11-yr-old, $43 \mathrm{~kg}$ boy was admitted with possible osteomyelitis of the left hip. He received IV penicillin, and a bone biopsy was scheduled. The child was otherwise well. He had undergone tonsillectomy three years earlier, receiving thiopentone, $\mathrm{N}_{2} \mathrm{O}$, and halothane without incident. The family history was unremarkable. On admission, the blood pressure was $130 / 80 \mathrm{mmHg}$. The physical examination was normal, apart from tenderness in the left hip.

One hour before surgery, the patient received meperidine $50 \mathrm{mg}$ and hydroxyzine $25 \mathrm{mg}$ IM. The patient's heart rate was 110 beats $\cdot \mathrm{min}^{-1}$ and blood pressure $130 / 85$ $\mathrm{mmHg}$. Anaesthesia was induced with thiamylal $200 \mathrm{mg}$ $\mathrm{IV}$, and maintained with 66 per cent $\mathrm{N}_{2} \mathrm{O}$ in $\mathrm{O}_{2}$, and two percent isoflurane by mask. No muscle relaxant was administered. Immediately, the heart rate increased to 140- 170 beats $\cdot \mathrm{min}^{-1}$ and the blood pressure to $220 / 130$ $\mathrm{mmHg}$, and reached as high as $240 / 180 \mathrm{mmHg}$. The patient received fentanyl $100 \mu \mathrm{g}$ and popranolol $1 \mathrm{mg} \mathrm{IV}$; $\mathrm{N}_{2} \mathrm{O}$ and isoflurane were continued. No muscle rigidity was noted, but the rectal temperature increased from 37.4 to $38.5^{\circ} \mathrm{C}$ within ten minutes of induction of anaesthesia.

The anaesthetic personnel made a presumptive diagnosis of $\mathrm{MH}$, discontinued $\mathrm{N}_{2} \mathrm{O}$ and isoflurane, and began treatment with IV dantrolene, surface cooling, and hyperventilation with 100 per cent $\mathrm{O}_{2}$ by mask. Sodium nitroprusside (SNP) IV stabilized the patient's blood pressure. An arterial blood sample, drawn from a left radial artery catheter, showed a respiratory acidosis (Table). Ten minutes later, the acidosis had worsened. Sodium bicarbonate $44 \mathrm{mEq}$ was administered IV. Twenty-five minutes after induction of anaesthesia, oral tracheal intubation was performed, using atracurium $20 \mathrm{mg} \mathrm{lV}$ for muscle relaxation.

A central venous pressure catheter was then inserted via the right internal jugular vein. The CVP was $16 \mathrm{~cm} \mathrm{H}_{2} \mathrm{O}$ after the administration of $1.5 \mathrm{~L}$ of cold normal saline solutions. Frothy, pink sputum appeared in the tracheal tube; furosemide $20 \mathrm{mg}$ IV was administered. Hypoxaemia did not occur (Table), but the $\mathrm{PaCO}_{2}$ decreased only with a minute ventilation of $20 \mathrm{~L} \cdot \mathrm{min}^{-1}$. 
TABLE Arterial blood gas analyses during hypermetabolic episode under anaesthesia

\begin{tabular}{lclclll}
\hline $\begin{array}{l}\text { Time after } \\
\text { induction }\end{array}$ & $\mathrm{pHa}$ & $\begin{array}{l}\mathrm{PCO}_{2} \\
(\mathrm{mmHg})\end{array}$ & $\begin{array}{l}\mathrm{PO}_{2} \\
(\mathrm{mmHg})\end{array}$ & $\begin{array}{l}\mathrm{HCO}_{3}^{-} \\
\left(\mathrm{mEq} \cdot \mathrm{L}^{-1}\right)\end{array}$ & $\mathrm{FlO}_{2}$ & $\begin{array}{l}\mathrm{K}^{+} \\
(\mathrm{mM})\end{array}$ \\
\hline $10 \mathrm{~min}$ & 7.16 & 73 & 84 & 25 & 1.0 & 5.1 \\
20 & 7.01 & 78 & 185 & 23 & 1.0 & 5.4 \\
40 & 7.26 & 55 & 203 & 25 & 1.0 & 4.2 \\
60 & 7.18 & 67 & 467 & 24 & 1.0 & 4.9 \\
90 & 7.17 & 67 & 259 & 24 & 1.0 & 5.3 \\
135 & 7.33 & 57 & 438 & 29 & 1.0 & 3.8 \\
175 & 7.36 & 49 & 80 & 27 & 0.5 & 3.8 \\
\hline
\end{tabular}

Three hours after the start of therapy, the patient's blood pressure was $130 / 90 \mathrm{mmHg}$, on $30-50 \mu \mathrm{g} \cdot \mathrm{min}^{-1}$ of SNP IV. The heart rate was $130-150$ beats $\cdot \mathrm{min}^{-1}$ and the CVP was $6 \mathrm{~cm} \mathrm{H}_{2} \mathrm{O}$. The patient had received 6 $\mathrm{mg} \cdot \mathrm{kg}^{-1}$ dantrolene $\mathrm{IV}$, and an infusion of dantrolene 7 $\mathrm{mg} \mathrm{hr}-1$ was started. The acidosis was resolving (Table), but the rectal temperature fluctuated from 36.5 to $38.7^{\circ} \mathrm{C}$. A single creatine kinase determination three hours after induction of anaesthesia was 73 IU (normal, 0-225 IU).

Several hours later, acute ischaemia developed in the left hand. After a poor response to papaverine infiltration and a left stellate ganglion block, a fasciotomy was performed with local anaesthesia. The colour of the hand improved. The blood pressure became more stable after the administration of IV hydralazine. The tracheal tube was removed $20 \mathrm{hr}$ after the episode. The patient received oral dantrolene $50 \mathrm{mg} \mathrm{Q6H}$ for the next $24 \mathrm{hr}$.

A cause for the hypertension was sought. The urinary vanillylmandelic acid (VMA) was elevated at 45.2 $\mathrm{mg} \cdot 24 \mathrm{hr}^{-1}$ (normal up to $6 \mathrm{mg}$ ). Computerized tomography of the abdomen revealed a left adrenal mass, consistent with a phaeochromocytoma. Oral prazosin and propranolol were begun.

Three weeks later, the patient underwent left adrenalectomy and removal of a phaeochromocytoma from the right adrenal gland. No prophylactic dantrolene was administered preoperatively. Anaesthesia was provided with thiamylal, fentanyl, $\mathrm{N}_{2} \mathrm{O}$, droperidol, and pancuronium; known $\mathrm{MH}$ triggering agents were avoided. The perioperative course was unremarkable.

Six months later, a quadriceps muscle biopsy and caffeine halothane contracture testing were performed. ${ }^{2}$ The contracture response to $2 \mathrm{mM}$ caffeine and to three per cent halothane were normal, and MH-susceptibility was ruled out.

\section{Discussion}

Phaeochromocytoma can mimic many disorders. It may first present as a hypermetabolic state during anaesthesia. The mortality under such circumstances is as high as 86 per cent. ${ }^{3}$ Temperature elevations up to $40^{\circ} \mathrm{C}, 4,5$ and lactic acidosis $(\mathrm{pH}$ as low as 6.67 , plasma lactate $\geq 22$ $\mathrm{mM})^{6-8}$ have been reported. Body temperatures $>40^{\circ} \mathrm{C}$ may develop with acute $\mathrm{MH},{ }^{1}$ but less dramatic temperature elevations are more common. Lactic acidosis may also occur during an acute $\mathrm{MH}$ episode. ${ }^{1}$

Hypertension may be the most prominent sign of phaeochromocytoma, ${ }^{3}$ particularly when it presents in the perioperative period. However, there are several possible aetiologies for the development of intraoperative hypertension, including acute $\mathrm{MH}^{9}$

Muscle rigidity has not been reported to occur with phaeochromocytoma, and may be a more specific sign of MH. ${ }^{10}$ However, muscle rigidity is absent in up to 25 per cent of acute $\mathrm{MH}$ episodes. " Thus, it may be very difficult to distinguish phaeochromocytoma from acute MH:

Phaeochromocytoma is an unusual tumour in the paediatric population. From 1954 to 1983 , only 16 children with this tumour were seen at the Mayo Clinic. ${ }^{12}$ In contrast to adults, phaeochromocytoma is more common in males than females (2:1). Children usually present with sustained rather than paroxysmal hypertension. Fewer malignant tumours, and more bilateral and extraadrenal tumours occur in children. There is also a higher incidence of multiple endocrine neoplasia (MEN) and familial disease in paediatric patients.

Recently, Crowley et al. reported a patient who developed a systolic blood pressure of $190 \mathrm{mmHg}$ and a heart rate of 145 beats $\cdot \mathrm{min}^{-1}$ during anaesthesia. ${ }^{13}$ The oesophageal temperature then increased by $1.6^{\circ} \mathrm{C}$. Arterial blood gas analysis showed a pH of 7.22, $\mathrm{PaCO}_{2}$ $56 \mathrm{mmHg}$, and serum bicarbonate $17 \mathrm{mM} \cdot \mathrm{L}^{-1}$. Therapy for acute MH was instituted; however, severe pulmonary oedema developed, followed by ventricular fibrillation. The patient survived, and was subsequently found to have a phaeochromocytoma. However, in-vitro contracture testing was not performed to rule out $\mathrm{MH}$-susceptibility.

As in the case of Crowley et al., the patient described here developed pulmonary oedema after the administration of IV propranolol. In a review of patients with undiagnosed phaeochromocytoma who died during surgery, pulmonary oedema frequently occurred before death. ${ }^{14}$ It has been suggested that propranolol may have induced pulmonary oedema ${ }^{13,15}$ by allowing unopposed alpha-mediated vasoconstriction, and by depressing myocardial contractility. Left ventricular dysfunction may already exist in some patients with phaeochromocytoma, ${ }^{16}$ predisposing them to heart failure.

It is interesting to speculate whether the administration of dantrolene had any effect on the outcome of either of these patients. In dogs, dantrolene selectively inhibits caffeine-induced catecholamine release, in a dose- 
dependent manner (84 per cent inhibition at $10 \mu \mathrm{M}$ concentration). ${ }^{17}$ Presumably, dantrolene affects calcium messenger systems in the adrenal medulla. ${ }^{18}$ Sumikawa et al. ${ }^{16}$ have suggested that part of the therapeutic action of dantrolene may be to attenuate the sympathetic response that occurs during an acute $\mathrm{MH}$ episode.

In conclusion, the development of a hypermetabolic state during anaesthesia is not pathognomonic of $\mathrm{MH}$. Other causes must be considered, particularly when unusual responses to treatment occur.

\section{References}

1 Rosenberg $H$. Clinical presentation of malignant hyperthermia. Br J Anacsth 1988; 60: 268-73.

2 Fletcher JE, Rosenberg $H$. Laboratory methods for malignant hyperthermia diagnosis. In: Williams $\mathrm{CH}$ (Ed.), Experimental Malignant Hyperthermia. New York: Springer-Verlag, 1988; 121-40.

3 Kirkendall WM, Liechry RD, Culp DA. Diagnosis and treatment of patients with phacochromocytoma. Arch Int Med 1965; 115: 529-36.

4 Kirby BD, Ham J, Fairley HB, Benowitz N. Schambelan $M$. Normotensive phaeochromocytoma: pharmacologic, paraneoplastic, and anaesthetic considerations. West J Med 1983; 139: 221-5.

5 Simon HB, Daniels $G H$. Hormonal hyprathermia: endocrinologic causes of fever. Am J Med 1979; 66: 257-63.

6 Madias NE, Goorno WE, Herson S. Severe lactic acidosis as a presenting feature of phacochromocytoma. Am J Kid Dis 1987; 10: 250-3.

7 Bornemann M, Hill SC, Kidd GS. Lactic acidosis in phcochromocytoma. Ann Int Med 1986; 105: 880-2.

8 Keller U, Mall T, Walter M, Bertel O, Mihatsch JM, Rite $R$. Phaeochromocytoma with lactic acidosis. Br Med J 1978; 2: 606-7.

9 Steward DA. Malignant hyperthermia - the acute crisis. Int Anesthesiol Clin 1979; 17: 1-9.

10 Larach MG, Rosenberg $H$, Larach DR, Broennly AM. Prediction of malignant hyperthermia susceptibility by clinical signs. Anesthesiology 1987; 66: 547-50.

11 Gronert GA. Malignant hyperthermia. In: Miller RD(Ed.). Anesthesia, 2nd ed. New York: Churchill-Livingstone, 1986: 1971-94.

12 Kaufman BH, Telander RL, van Heerden JA, Zimmerman $D$, Sheps SG, Dawson B. Pheochromocytoma in the pediatric age group: current status. J. Ped Surgery 1983; 18: 879-84.
13 Crowley KJ, Cunningham AJ, Conroy $B, O^{\prime}$ Connell $P R$, Collins $P G$. Phaeochromocytoma - a presentation mimicking malignant hyperthermia. Anaesthesia 1988; 43 : 1031-2.

14 St. John Sutton MG, Sheps SG, Lie JT. Prevalence of clinically unsuspected pheochromocytoma: review of a 50-ycar autopsy serics. Mayo Clin Proc 1981; 56: 354-60.

15 Sloand EM, Thompson BT. Propranolol-induced pulmonary cdema and shock in a patient with pheochromocytoma. Arch Int Med 1984; 144: 173-4.

16 Gilsanz FJ., Luengo C, Conejero P, Peral P, Avello F. Cardiomyopathy and phaeochromocytoma. Anaesthesia 1983; 38: 888-91.

17 Sumikawa K, Hayashi Y, Fukumitsu K, Yoshiya I. Selective inhibition by dantrolene of caffeine-induced catecholamine release from perfused dog adrenals. Res Commun Chem Pathol Pharmacol 1987; 57: 45-53.

18 Rasmussen $H$. The calcium messenger system (part 2). N Engl J. Med 1986; 314: 1164-70. 